\title{
cis- and trans-acting sequences required for expression of simian virus 40 genes in mouse oocytes
}

\author{
Lorraine E. Chalifour, ${ }^{1}$ Dana O. Wirak, ${ }^{2}$ Ulla Hansen, ${ }^{3}$ Paul M. Wassarman, ${ }^{4}$ and Melvin L. \\ DePamphilis $^{4}$
}

Department of Biological Chemistry, Harvard Medical School, Boston, Massachusetts 02115 USA

To determine the requirements for gene expression in mammalian germ cells, circular double-stranded simian virus 40 (SV40) DNA molecules containing deletions in sequences controlling transcription and replication were injected into the nucleus of mouse oocytes. Expression of large $(\mathrm{T}-\mathrm{Ag})$ and small $(\mathrm{t}-\mathrm{Ag})$ tumor antigens ("early gene products") required at least three GGGCGG boxes, but did not require either the origin of viral DNA replication (ori) or a TATA box. Expression of capsid antigen VP1 ("late gene products") required at least three GGGCGG boxes, sequences between nucleotides 197 and 273 in the 72-bp repeat region, and transactivation by T-Ag. These results are consistent with the requirements for expression of the same genes in differentiated mammalian cells. Surprisingly, however, the 72-bp repeats ("enhancer elements") that are required for expression of $\mathrm{T}$ - $\mathrm{Ag}$ and $\mathrm{t}$ - $\mathrm{Ag}$ genes in differentiated cells were not required in mouse oocytes. Similarly, expression of both the early and late genes was unaffected in mouse oocytes by the absence of either DNA replication or an intact ori sequence, components required for maximum expression of late genes in differentiated cells. Thus, mammalian oocytes effectively utilize promoters that are fully active in mammalian differentiated cells only when associated with either enhancer elements or DNA replication. Furthermore, requirements for expression of SV40 genes in mouse oocytes are distinctly different from those reported for Xenopus oocytes. This suggests that caution should be exercised when extrapolating conclusions drawn from experiments with amphibian germ cells to mammalian germ cells.

[Key Words: SV40; enhancer; promoter; trans-activation; mouse; oocyte]

Received May 20, 1987; revised version accepted October 1, 1987.

At least five types of cis-acting sequence elements have been identified as components in the regulation of eukaryotic gene transcription (for review, see Yaniv 1984; McKnight and Tjian 1986). A TATA box with a consensus sequence of TATAAA is generally located 25-30 bp upstream from the beginning of the transcribed sequence. Mutations in the TATA box increase the heterogeneity of transcriptional start sites, but do not always significantly reduce the level of transcription. Further upstream $(-40$ to $-100 \mathrm{bp})$ are CAAT sequences and GGGCGG boxes that function as part of the promoter. Loss of these elements can dramatically decrease rates of transcription. Finally, a variety of sequences, in either orientation, enhance gene expression from distances as great as $1000 \mathrm{bp}$, usually in a tissue-specific manner. Examples of specific binding proteins have been demon-

\footnotetext{
Present addresses:

'National Research Council, Biotechnology Research Institute, Montreal, Quebec, Canada H4P 2RD.

${ }^{2}$ Molecular Therapeutics, West Haven, Connecticut 06116 USA.

${ }^{3}$ Dana-Farber Cancer Center, Boston, Massachusetts 02115 USA.

${ }^{4}$ Roche Institute of Molecular Biology, Roche Research Center, Nutley, New Jersey 07110 USA.
}

strated for each of these elements, revealing the presence of trans-acting factors. Origins of DNA replication (ori) can also stimulate expression of specific genes [e.g., late genes of simian virus 40 (SV40), polyoma virus, and adenovirus (Acheson 1981; Thomas and Mathews 1980)] by increasing the number of gene copies and/or by activating the promoter.

Data that define these regulatory elements are derived largely from studies of viral and cellular genes in cultured differentiated cell lines, as well as in subcellular systems capable of transcribing bare DNA. Analysis of the role of cis-and trans-acting factors that control eukaryotic gene expression in germ cells has been limited to injection of DNA into Xenopus laevis oocytes, where their large size $(>1 \mathrm{~mm})$ and ability to express foreign genes introduced into their nucleus, or germinal vesicle, make them a convenient in vivo system. However, differences probably exist in the developmental biology of amphibians and mammals that preclude extrapolation of results obtained with amphibians directly to mammals. For example, Xenopus eggs inherit sufficient maternal mRNA and proteins to maintain cell division for 12 
cleavages before zygotic genes are expressed, whereas fertilized mouse eggs undergo only one cleavage before initiating zygotic gene transcription (Slack 1983). The size of the store of maternally inherited materials may account for the fact that DNA injected into Xenopus eggs replicates without any sequence requirements, whereas DNA injected into fertilized mouse eggs has sequence requirements similar to those found in mouse differentiated cells (Wirak et al. 1985). Thus, it is not clear whether genes expressed in selected mammalian differentiated cells are also expressed in mammalian oocytes, and, if so, whether expression depends on the same regulatory elements. We investigated this question using SV40 genes and mouse oocytes.

SV40 genes are normally expressed in mammalian cells and temporally regulated by both cis-acting and trans-acting elements in a species-specific manner. SV40 replicates in nuclei of permissive monkey and human cells, where cellular components transcribe and translate large and small tumor antigens $(\mathrm{T}-\mathrm{Ag}$ and $\mathrm{t}-\mathrm{Ag}$, respectively) soon after infection ("early gene expression"). T-Ag then induces synthesis of cellular proteins required for DNA replication and chromatin assembly, initates replication of viral DNA, and participates in activation of the late gene promoter (DePamphilis and Bradley 1986). Early gene expression also occurs in SV40-infected or transformed mouse fibroblasts, but mouse differentiated cells are nonpermissive for viral DNA replication and late gene expression. SV40 DNA replication is not detected in mouse fibroblasts /Chia and Rigby 1981), and SV40 late gene expression is only $1-5 \%$ of the amount of early gene expression (Parker and Stark 1979; Ernoult-Lange and May 1983). Synthesis of the major capsid protein VP-1 (V-Ag) can be detected in mouse fibroblasts, but it requires about 1000 -fold more viral DNA per nucleus than required to observe T-Ag synthesis (Graessman et al. 1976).

In contrast to mouse differentiated cells, both early and late genes are expressed concurrently and in equivalent amounts when SV40 DNA is injected into the germinal vesicle of a single mouse oocyte that is maintained in a transcriptionally and translationally active state (Chalifour et al. 1986). The level of SV40 protein synthesis in a single oocyte is about the same as in 1000 virus-infected CV-1 cells. Neither SV40 nor polyoma virus DNA replicates when injected into the germinal vesicle of mouse oocytes, cells that are arrested in the first meiotic prophase (Chalifour et al. 1986). Thus, the response of the SV40 late gene promoter appeared strikingly different from that observed in either mouse or monkey differentiated cells. Moreover, both early and late SV40 genes are rapidly expressed in Xenopus oocytes where expression of SV40 late genes does not require T-Ag (Miller and Mertz 1982; Michaeli and Prives 1985). These results suggest that control of gene expression in germ cells is significantly different than in somatic cells. Therefore, a variety of deletion mutants in the SV40 noncoding region (nucleotides 5171-304) that removed cis-acting transcriptional regulatory elements involved in early and/or late gene expression were tested for their ability to produce $\mathrm{T}-\mathrm{Ag}, \mathrm{t}-\mathrm{Ag}$, and $\mathrm{V}-\mathrm{Ag}$ fol- lowing injection into the nucleus of mouse oocytes. Our results revealed that the requirements for expression of these genes in mouse oocytes are similar to those observed following SV40 DNA replication in a lytic infection of permissive monkey cells, but distinctly different from expression in Xenopus oocytes.

\section{Results}

\section{Experimental approach}

Previous studies with wild-type SV40 DNA demonstrated that $\mathrm{T}-\mathrm{Ag}, \mathrm{t}-\mathrm{Ag}$, and $\mathrm{V}-\mathrm{Ag}$ were synthesized at equivalent rates in mouse oocytes and that the nascent proteins were stable (Chalifour et al. 1986). Therefore, a series of overlapping deletions in the SV40 early and late gene control region (nucleotides 5171-304; Fig.1) were examined for their ability to express $\mathrm{T}-\mathrm{Ag}, \mathrm{t}-\mathrm{Ag}$, and $\mathrm{V}-\mathrm{Ag}$ in mouse oocytes. These deletions were all contained in an otherwise complete SV40 genome that had been opened at the BamHI site and cloned into pMK16 so that nonviable deletions could be propagated in $E$. coli. Plasmid DNA was purified, and the SV40 genome was excised, recircularized by the action of DNA ligase, and then injected into the germinal vesicle of mouse oocytes as previously described (Chalifour et al. 1986). From 17,000 to 85,000 DNA molecules were injected into each oocyte. On a volume basis, this was equivalent to injecting a single differentiated cell with $80-400$ DNA copies. Injected oocytes were cultured for 12-16 $\mathrm{hr}$ in the presence of dibutyl cAMP to prevent meiotic maturation and $\left.{ }^{35} \mathrm{~S}\right]$ methionine to radiolabel nascent viral proteins. Viral antigens were then immunoprecipitated with anti-T and anti-V sera, solubilized in sodium dodecylsulfate (SDS), and fractionated by electrophoresis in SDS-polyacrylamide gels (Chalifour et al. 1986). The electrophoretic mobility of nascent antigens synthesized in mouse oocytes was indistinguishable from the mobility of those synthesized after SV40 infection of CV-1 cells, and uninjected oocytes and mock-infected CV-1 cells did not produce immunoprecipitable ${ }^{35} S$-labeled proteins that comigrated with any viral antigen. Wildtype SV40 genome (JYM) was excised from plasmid pJYM (Lusky and Botchan 1981) and used as a standard of comparison in each experiment. Each experiment was repeated several times, and data were quantitated and standardized relative to $\mathrm{T}-\mathrm{Ag}$ expression from JYM as described in Table 1.

cis-acting sequences required for SV40 early and late gene expression in mouse oocytes: ori and TATA box

In mammalian differentiated cells, the early gene promoter includes a nonessential TATA box located within the ori core (Benoist and Chambon 1981). The late promoter has no recognizable TATA sequence which may explain the large number of heterogeneous start sites for late mRNA. Although ori is not required for early gene expression (Fromm and Berg 1982, 1983a; Wasylyk et al. 1983|, some studies indicate that ori is required for late gene expression (Contreras et al. 1982; Hartzell et al. 




Figure 1. cis-acting SV40 seqeunces required for expression of early and late genes in differentiated mammalian cells are diagrammed, and the various deletions used in this study are indicated. Landmarks include the 72-bp repeats ("enhancer elements"), six GGGCGG boxes that are part of the early and late gene promoters, TATA box, a 27-bp palindrome, three T-Ag DNA binding sites of decreasing affinity $(1>2>3)$, and the origin of DNA replication consisting of a 64-bp core sequence that is absolutely required for replication, flanked by two auxiliary sequences that facilitate replication two- to threefold, with the beginning of continuous DNA synthesis on each strand indicated by an arrow (origin of bidirectional replication; for review, see DePamphilis and Bradley 1986). Start sites for early-early (E-E), late-early (L-E) and late (L) mRNAs are indicated. Nucleotide numbering system is that of Buchman et al. (1981).

1984a,b; Brady and Khoury 1985), whereas other studies indicate only a minor involvement (Brady et al. 1984a; Ernoult-Lange et al. 1984; Keller and Alwine 1984, 1985). Since ori contains T-Ag DNA binding site 2 (Fig. 1), ori may be required as a binding site for $\mathrm{T}-\mathrm{Ag}$ rather than to initiate DNA replication. T-Ag mutants that no longer bind specifically to ori are also unable to activate late genes (Brady et al. 1984b; Keller and Alwine 1984). Activation of late genes requires $\mathrm{T}$-Ag binding site 2 and one of the 72-bp repeats (Brady and Khoury 1985; Hartzell et al. 1984a,b|, although some studies have found $\mathrm{T}-\mathrm{Ag}$ activation dependent only upon seqences in the junction between the 72-bp repeats (Keller and Alwine 1985; Ernoult-Lange et al. 1987).

To determine whether or not mouse oocytes require ori or a TATA box for SV40 gene expression, ori- mutants were injected into the germinal vesicle. Mutant $\Delta 6-1$ carries a 6-bp deletion in the ori core sequence of SV40 (Fig.1) that renders it incapable of replicating in permissive monkey cells, but does not affect its ability to bind T-Ag (Gluzman 1981; Buchman et al. 1984). Deletion X39 is missing nucleotides 34-5237, which encompass most of ori core, T-Ag DNA binding site 2, and the TATA box (Fromm and Berg 1982). Both of these mutants not only produced levels of $\mathrm{T}-\mathrm{Ag}$ and $\mathrm{t}-\mathrm{Ag}$ equivalent to wild-type SV40, but produced $20-30 \%$ more V-Ag than did wild-type DNA (Fig. 2; Table 1). The ratio of $\mathrm{V}-\mathrm{Ag}$ to $\mathrm{T}-\mathrm{Ag}$ in oocytes injected with SV40 DNA, CV-1 cells transfected with SV40 DNA, and CV-1 cells infected with SV40 virus was always $3: 1$ to $4: 1$ (Fig. 5; Table 1). Reducing the amount of DNA injected by 10 -fold (1700 copies per oocyte) reduced protein synthesis threefold, but the ratio of $\mathrm{T}-\mathrm{Ag}$ to $\mathrm{V}-\mathrm{Ag}$ remained the same (Chalifour et al. 1986). Thus, neither a functional ori nor a TATA box is required for expression of early and late SV40 genes in mouse oocytes, and T-Ag DNA binding site 2 is not necessary for $\mathrm{V}$-Ag expression.

\section{GGGCGG boxes}

The early gene promoter in differentiated cells includes a series of six GGGCGG boxes that make up three 21-bp direct repeats. At least one GGGCGG box is needed for efficient transcription of the early region in vivo (Benoist and Chambon 1981; Fromm and Berg 1982; Everett et al. 1983; Baty et al. 1984; Barrera-Saldana et al. 1986) and in vitro (Hansen and Sharp 1983; Vigneron et al. 1984; Gidoni et al. 1985; Barrera-Saldana et al. 1986). GGGCGG boxes, which are active in either orientation (Everett et al. 1983; Vigneron et al. 1984), maximize transcription of late genes both in vivo (Fromm and Berg 1982; Hartzell et al. 1984a,b) and in vitro (Hansen and Sharp 1983; Brady et al. 1984a; Rio and Tjian 1984; Vigneron et al. 1984; Gidoni et al. 1985). In the absence of the 72-bp repeats, GGGCGG boxes $4-6$ have the greatest effect on late promoter activity in vitro, whereas boxes $1-3$ have the greatest effect on early promoter activity in vitro (Gidoni et al. 1985). However, GGGCGG boxes 4-6 are 
not necessary in vivo if the 72 -bp repeats are present (Fromm and Berg 1983a; Hartzell et al. 1984a; Omilli et al. 1986).

Deletions XS7, XS14, XS15, and XS16 progressively removed the GGGCGG boxes from SV40 DNA (Fig. 1). Mutant XS7, in which GGGCGG boxes 4-6 were deleted, expressed $\mathrm{T}-\mathrm{Ag}, \mathrm{t}-\mathrm{Ag}$, and $\mathrm{V}-\mathrm{Ag}$ at levels comparable to those produced by JYM in the same experiment (Fig. 3; Table 1). However, deletion of GGGCGG boxes 3-6 in XS14 resulted in a fourfold decrease in the synthesis of $\mathrm{T}-\mathrm{Ag}$ and $\mathrm{t}-\mathrm{Ag}$, and a sevenfold decrease in the synthesis of V-Ag. Deletion mutant XS15 retained only part of GGGCGG box 1, and XS16 was missing all six GGGCGG boxes but retained the TATA sequence. Synthesis of both early and late viral proteins in XS15- and XS16-injected oocytes was reduced more than 20-fold. Therefore, retention of GGGCGG boxes 1, 2, and 3 was sufficient for maximum expression of early or late genes; two boxes gave partial early gene expression, and one box was insufficient for expression of either early or late genes.

\section{2-bp repeats (enhancer elements)}

Transcription from the SV40 promoter is stimulated in differentiated cells approximately 100 -fold by the presence of at least three enhancer elements, contained within the 72-bp repeat region, that impart a broad hostrange specificity (Herr and Clarke 1986; Zenke et al. 1986; Wildeman et al. 1986; Schirm et al. 1987). A single 72-bp repeat is essential for expression of $\mathrm{T}$ - $\mathrm{Ag}$ in vivo (Fromm and Berg 1982, 1983a). trans-activation of late gene expression by $\mathrm{T}-\mathrm{Ag}$ also requires sequences in the 72-bp repeats (Hartzell et al. 1984a,b; Brady and Khoury 1985; Keller and Alwine 1985; Ernoult-Lange et al. 1987). Therefore, the importance of these sequences in expressing SV40 genes in mouse oocytes was examined.

Deletions in mutants XS11, XS13, and S232 (Fig. 1) progressively removed the 72 -bp repeats that function as enhancer elements (Fig. 1). XS11 is missing the first 72-bp repeat and part of the second. XS13 is missing both 72-bp repeats, and $\mathrm{S} 232$ has deleted both 72 -bp repeats, as well as all of the major late mRNA initiation sites.

Table 1. Quantitative analysis of promoter activity

\begin{tabular}{|c|c|c|c|c|c|c|c|}
\hline \multirow{2}{*}{$\begin{array}{l}\text { Function } \\
\text { deleted }\end{array}$} & \multirow[b]{2}{*}{ DNA } & \multirow{2}{*}{$\begin{array}{l}\text { Number of } \\
\text { experiments }\end{array}$} & \multirow[b]{2}{*}{ JYM } & \multicolumn{4}{|c|}{ Relative expression $(\%)$} \\
\hline & & & & Total & $\mathrm{T}-\mathrm{Ag}$ & $t-A g$ & $\mathrm{~V}-\mathrm{Ag}$ \\
\hline none & JYM & 15 & - & $(100)$ & $(100)$ & 100 & 340 \\
\hline ori & $\Delta 6-1$ & 4 & - & $107 \pm 10$ & 100 & 100 & 410 \\
\hline ori + TATA & X39 & 5 & - & $110 \pm 9$ & 95 & 95 & 475 \\
\hline \multirow[t]{7}{*}{ GGGCGG boxes } & XS7 & 5 & - & $100 \pm 13$ & 100 & 100 & 240 \\
\hline & & 2 & + & & 420 & 220 & 250 \\
\hline & XS14 & 5 & - & $24 \pm 6$ & 21 & 26 & 47 \\
\hline & & 2 & + & & 300 & 600 & 21 \\
\hline & $\mathrm{XS} 15$ & 5 & - & $7 \pm 2$ & 4 & 11 & 11 \\
\hline & & 2 & + & & 280 & 700 & 5 \\
\hline & XS16 & 5 & - & $6 \pm 2$ & 8 & 4 & 24 \\
\hline \multirow[t]{2}{*}{ GGGCGG boxes + enhancer } & XS6 & 5 & - & $14 \pm 2$ & 12 & 0 & 54 \\
\hline & & 2 & + & & 100 & 92 & 10 \\
\hline \multirow[t]{4}{*}{ Enhancer } & XS11 & 4 & - & $130 \pm 12$ & 160 & 150 & 270 \\
\hline & XS13 & 5 & - & $105 \pm 7$ & 110 & 125 & $90(115)$ \\
\hline & S232 & 5 & - & $136 \pm 12$ & 130 & 160 & $160(172)$ \\
\hline & $\mathrm{S} 113$ & 5 & - & $99 \pm 6$ & 150 & 130 & 52 \\
\hline Late leader & $\Delta \mathrm{LL}$ & 1 & - & & 100 & 100 & 0 \\
\hline \multirow{4}{*}{$\mathrm{T}-\mathrm{Ag}$} & $\mathrm{SV} \Delta \mathrm{T}$ & 10 & - & & 0 & & 0 \\
\hline & & 2 & + & & 100 & & 300 \\
\hline & SV2770 & 2 & - & & 0 & & 0 \\
\hline & & 2 & + & & 100 & & 250 \\
\hline $\mathrm{V}-\mathrm{Ag}$ & pJYM & 10 & - & & 110 & & 0 \\
\hline
\end{tabular}

Function deleted in each mutant DNA is indicated in Fig. 1. JYM is a wild-type SV40 carried in the plasmid pJYM. The relative amount of each ${ }^{35}$ S-labeled antigen was determined by densitometry, using at least two different fluorograms exposed for varying periods of time to ensure that each band was clearly resolved and that the intensity of each band was proportional to its $\left[{ }^{35} \mathrm{~S}\right] \mathrm{methio}-$ nine content. These data were then divided by the number of methionine residues per antigen $(22 / \mathrm{T}-\mathrm{Ag}, 9 / \mathrm{t}-\mathrm{Ag}$, and $7 / \mathrm{V}-\mathrm{Ag})$. In each experiment, one group of oocytes was injected with JYM, and the total amount of gene expression by JYM was defined as $100 \%$. Total gene expression $\{[$ mutant $(T+t+V) \div J Y M(T+t+V)] \times 100\}$ was then calculated relative to JYM in the same experiment. The number of experiments and the standard error of the mean $(\mathrm{SEM}=\sigma / \sqrt{\mathrm{N}})$ are indicated for each DNA sample. ${ }^{35} \mathrm{~S}-\mathrm{Labeled} \mathrm{T}-\mathrm{Ag}$ synthesized by JYM in each experiment was also defined as $100 \%$, and the amounts of $\mathrm{t}-\mathrm{Ag}$ and $\mathrm{V}$ - $\mathrm{Ag}$ synthesized by JYM were then calculated relative to T-Ag synthesized by JYM. The amounts of T-Ag $[($ mutant $\mathrm{T}-\mathrm{Ag} \div \mathrm{JYM} \mathrm{T-Ag}) \times 100], \mathrm{t}-\mathrm{Ag}[(\mathrm{mutant} \mathrm{t}-\mathrm{Ag} \div \mathrm{JYM}$ $\mathrm{t}-\mathrm{Ag}) \times 100]$, and $\mathrm{V}-\mathrm{Ag}[($ mutant $\mathrm{V}-\mathrm{Ag} \div \mathrm{JYM} \mathrm{V-Ag}) \times 100]$ synthesized by each mutant tested in the same experiment were then calculated relative to gene expression by JYM. Plasmid pIYM was either coinjected $|+|$ or not coinjected $|-|$ with the mutant DNA in a 1:1 ratio. Numbers in parentheses for XS13 and S232 are relative amounts of V-Ag if the smaller 'VP protein' is added to the VP-1 protein (see Fig. 4). 
Figure 2. T-Ag and V-Ag expression in the absence of a functional origin of replication. SV40 DNA from plasmids $\mathrm{p} \Delta 6-1$, pX39, and pJYM was cut, religated to generate topologically relaxed, circular SV40 DNA, and then injected into mouse oocytes as described in Materials and methods. Survivors were metabolically labeled overnight in $\left[{ }^{35} \mathrm{~S}\right]$-methionine $(1 \mathrm{mCi} /$ $\mathrm{ml}$ )-containing media. After labeling, 30 injected oocytes were lysed and then treated with anti- $\mathrm{T}$ and anti- $\mathrm{V}$ sera to immunoprecipitate $\mathrm{T}-\mathrm{Ag}, \mathrm{t}-\mathrm{Ag}$, and $\mathrm{V}-\mathrm{Ag}$. $\left[{ }^{35} \mathrm{~S}\right]-$ Proteins in the immunoprecipitates were separated by electrophoresis in an SDS-polyacrylamide gel, and the gel was processed for fluorography. Mock-infected or SV40-infected CV-1 cells served as controls. Lanes: $(a)$ uninjected oocytes; $(b) \Delta 6-1 ;(c)$ X39; $(d)$ wild-type SV40 DNA (JYM); $(e)$ mock-infected CV-1; $(f)$ SV40-infected $\mathrm{CV}-1$. The positions of $\mathrm{T}-, \mathrm{t},-$ and $\mathrm{V}-\mathrm{Ag}$ are indicated by arrows. This experiment was repeated four times.

S113 is missing only the distal portion of one of the 72-bp repeats and several late mRNA initiation sites. All of these mutants produced as much or more $\mathrm{T}-\mathrm{Ag}$ and t-Ag as wild-type SV40 (Fig. 4; Table 1), demonstrating that activation of the early gene promoter does not require an enhancer element. Removal of the first 72-bp repeat (XS11) had no effect on V-Ag expression, but removal of both 72-bp repeats (XS13) reduced the fraction of V-Ag synthesis about sevenfold (Fig. 4; table 1). Extending this deletion further to remove one (S113) or all major late mRNA start sites (S232), slightly stimulated $\mathrm{T}-\mathrm{Ag}$ and $\mathrm{t}-\mathrm{Ag}$ expression, although $\mathrm{V}-\mathrm{Ag}$ expression remained sixfold lower than that observed with JYM. Therefore, nucleotides 197-273 were required for maximal expression of late genes in oocytes, although not to the extent to which the GGGCGG boxes were required.

\section{Basal level of gene expression}

Some $\mathrm{T}-\mathrm{t} \mathrm{t}-$, and $\mathrm{V}-\mathrm{Ag}$ were detected in the preceding experiments, regardless of the deletion examined. To determine the level observed in the absence of any regulatory seqeunce (i.e., the basal level of gene expression), mutant XS6 was examined, in which all GGGCGG boxes and both 72-bp repeats were deleted (Fig. 1). XS6 produced 10 -fold less $\mathrm{T}$-Ag and sixfold less $\mathrm{V}$-Ag than JYM (Fig.4; Table 1). Thus, since none of the deletions between 5236 and 346 (Fig. 1) eliminated all of the major early or late mRNA initiation sites, mouse oocytes appeared capable of initiating mRNA synthesis on injected DNA, albeit at a low level, even in the absence of recognized regulatory sequences. To determine whether or not a correct mRNA was necessary for gene expression in oocytes, nucleotides $364-833$ were deleted $(\Delta L L$, Fig. 1). This sequence encompassed the leader and $5^{\prime}$-splice site for late mRNA, but left major late mRNA start sites

Figure 3. Effect of deletions in the 21-bp repeats on $\mathrm{T}-\mathrm{Ag}, \mathrm{t}-\mathrm{Ag}$, and V-Ag gene expression. Mutant SV40 DNA XS7 (lane $b$ ), XS14 (lane $c$ ), XS15 (lane $d$ ), XS16 (lane $e$ ), and wild-type SV40 DNA (JYM, lane $f$ ) were injected into mouse oocytes and processed as described in Fig.2. Lane $a$ contains uninjected oocytes. This experiment was repeated four times.

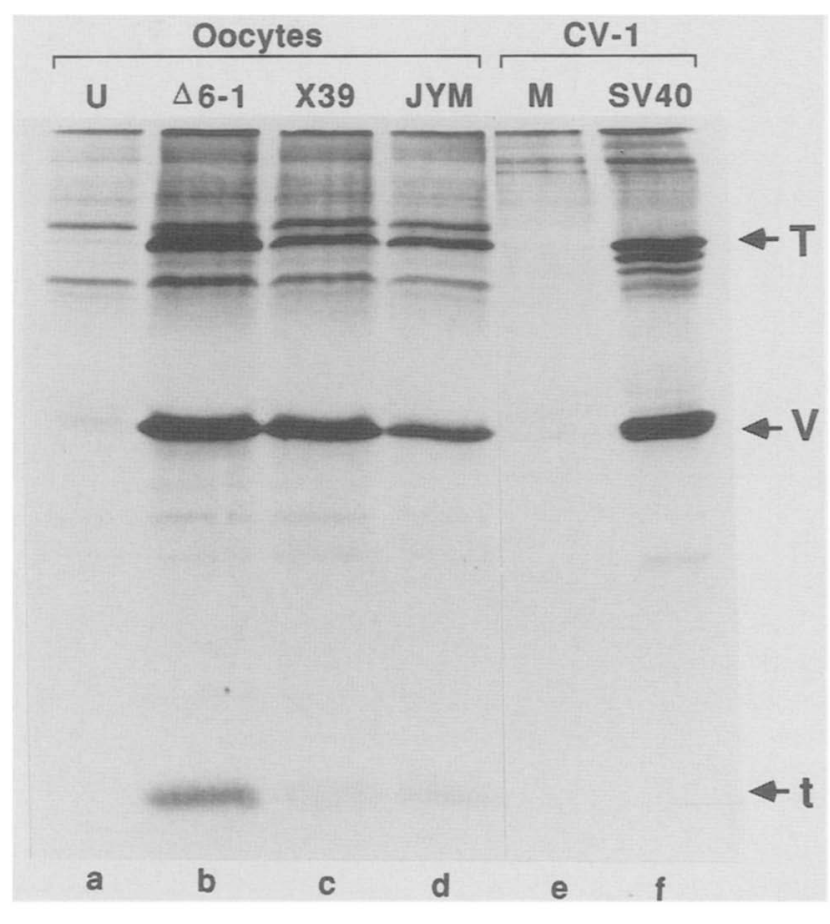

intact, and it was absolutely required for synthesis of $\mathrm{V}$-Ag in oocytes. As expected, deletion of the late mRNA leader sequence had no effect on synthesis of early gene products (Fig. 4; Table 1)

\section{Trans-activation of the late gene promoter by T-antigen}

Expression of SV40 late genes in permissive monkey cells requires the presence of $\mathrm{T}-\mathrm{Ag}$ (Brady et al. $1984 \mathrm{~b}$; Hartzell et al. 1984a,b; Keller and Alwine 1984, 1985;

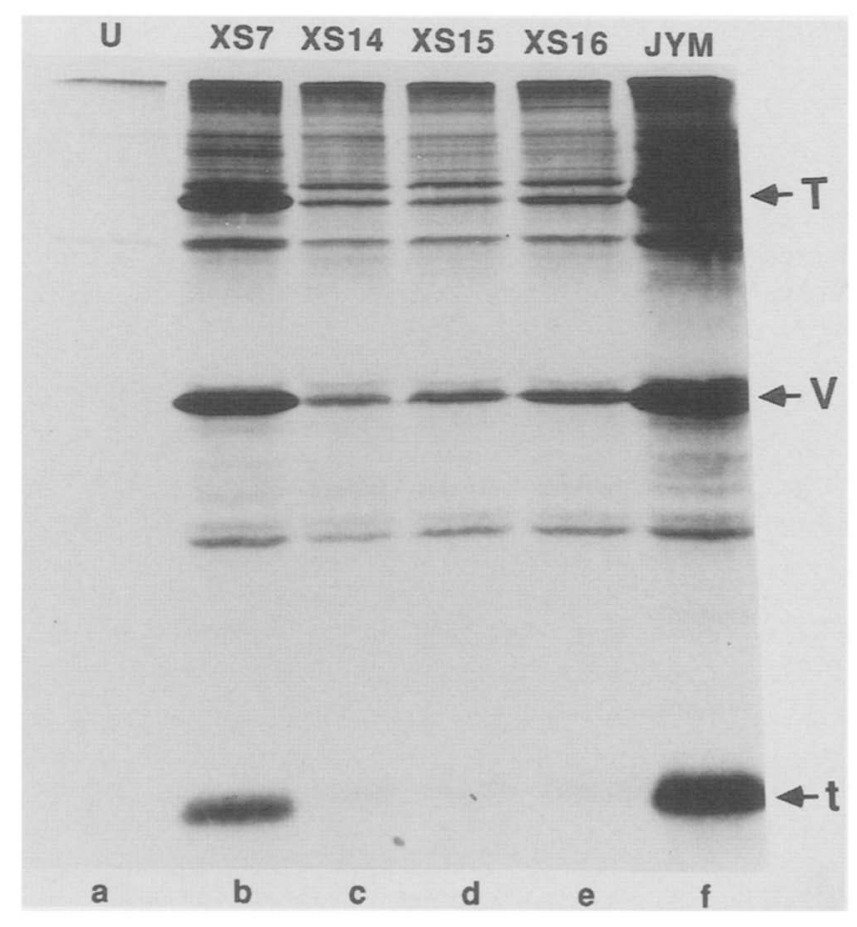




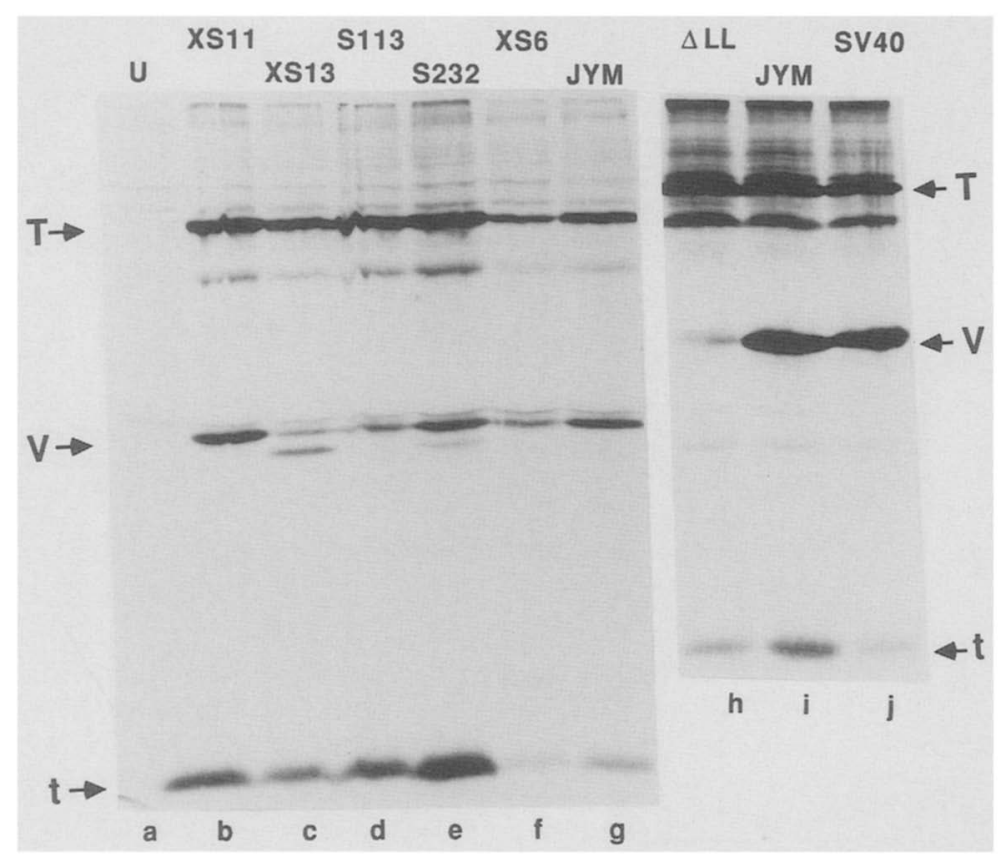

Figure 4. Requirement of 72-bp repeats for synthesis of $\mathrm{V}-\mathrm{Ag}$ but not $\mathrm{T}-\mathrm{Ag}$, in mouse oocytes. $\mathrm{Mu}$ tant SV40 DNA XS11 (lane b), XS13 (lane $c$ ), S113 (lane $d$ ), S232 (lane $e$ ), XS6 (lane $f$ ), and $\Delta \mathrm{LL}$ (lane $h$ ), and wild-type SV40 DNA (JYM, lanes $g$ and $i$ ) and wt800 SV40 DNA (lane $j$ ) were injected into oocytes and processed as described in Fig. 2. Lane $a$ contains uninjected oocytes. This experiment was repeated four times.
Brady and Khoury 1985; Shaw et al. 1985), whereas expression of these genes in Xenopus oocytes is independent of T-Ag (Miller et al. 1982; Michaeli and Prives 1985). Therefore, to determine whether or not T-Ag was required to activate the late gene promoter in mouse oocytes, two plasmids were constructed that could express $\mathrm{V}$-Ag but not T-Ag. In plasmid pSV $\Delta \mathrm{T}, 1018 \mathrm{bp}$ of the central portion of the T-Ag structural gene was deleted. SV40 seqeunces were excised from pSV $\Delta \mathrm{T}$ and recircularized (SV $\Delta \mathrm{T}$ ) before testing for expression of $\mathrm{T}-\mathrm{Ag}$ and $\mathrm{V}-\mathrm{Ag}$. This T-Ag minus SV40 genome synthesized V-Ag when transfected onto COS-7 cells (Fig. 5), a CV-1-derived cell line that synthesized $\mathrm{T}-\mathrm{Ag}$ from an integrated SV40 ori-defective genome. Neither T-Ag nor V-Ag were synthesized after transfection of CV-1 cells. In contrast, CV-1 and COS-7 cells transfected with JYM DNA or infected with wild-type SV40 synthesized both T-Ag and $\mathrm{V}$-Ag. Similar results were obtained by transfecting cells with plamid pSV2770, which consisted of the entire wild-type SV40 sequences interrupted at the carboxyterminal portion of the SV40 T-Ag structural gene, at nucleotide 2770 , by the vector pML-1 (data not shown). Thus, as previously reported, V-Ag was not synthesized in permissive monkey cells in the absence of a functional T-Ag gene.

SVAT or pSV2770 injected into the germinal vesicle of a mouse oocyte produced neither T-Ag nor V-Ag (Fig. 6; Table 1). Injection of plasmid pJYM alone produced T-Ag but not V-Ag, because the SV40 VP-1 gene in PJYM is interrupted at nucleotide 2533 by pML-1 sequences (Lusky and Botchan 1981). However, when SVAT or SV2770 was coinjected with pJYM, both T-Ag and V-Ag were synthesized (Fig. 6). Therefore, T-Ag (encoded by pJYM) was required to activate late gene expression in nonpermissive mouse oocytes, as well as in permissive monkey cells.

trans-activation of the $\mathrm{V}$-Ag gene by $\mathrm{T}-\mathrm{Ag}$ in oocytes raised the question of whether or not the cis-acting sequences required for $\mathrm{V}-\mathrm{Ag}$ expression were part of the late gene promoter or were required only for expression of T-Ag which then activated late genes. Therefore, XS6 was coinjected with pJYM in a $1: 1$ ratio to determine whether synthesis of $\mathrm{T}-\mathrm{Ag}$ from $\mathrm{pJYM}$ would induce synthesis of $\mathrm{V}-\mathrm{Ag}$ from XS6. $\mathrm{V}-\mathrm{Ag}$ was not expressed (Fig. 6; Table 1), even though the level of T-Ag expression was equal to that produced by X39, where V-Ag expression was consistently high (Fig. 6; Table 1). Similarly, providing $\mathrm{T}-\mathrm{Ag}$ in trans neither compensated for loss of the four to six GGGCGG boxes deleted in mutants XS14 and XS15, nor did it stimulate further synthesis of $\mathrm{V}-\mathrm{Ag}$ in mutant XS7, in which only three GGGCGG boxes were missing (Table 1). Therefore, all of the cis-acting sequences that were identified above as important or late gene expression in mouse oocytes functioned as part of the late gene promoter.

\section{Discussion}

DNA sequence requirements for expression of SV40 early and late genes (Fig. 1) have been well studied both in vivo and in vitro using differentiated cells from permissive (monkey and human) and nonpermissive (mouse) mammals. These and other studies have revealed at least four major cis-acting sequence elements and one trans-acting gene product that are important for control of gene expression in mammalian somatic cells: GGGCGG boxes, enhancers, origins of DNA replication, TATA boxes, and virally encoded tumor antigen. 




Figure 5. V-Ag gene expression in differentiated cells requires trans-activation by T-Ag. SV40 DNA from pSV $\Delta$ T and pJYM was prepared as described in Materials and methods. COS-7 (lanes $a-c$ ) or CV-l cells (lanes $d-f$ ) were then transfected (Luthman and Magnusson 1983) with SV $\Delta \mathrm{T}$ (lanes $b, e$ ) or JYM (lanes $c, f$ ), labeled with $\left[{ }^{35} \mathrm{~S}\right.$ )-methionine $48 \mathrm{hr}$ later (Chalifour et al. 1986), and nascent T-Ag and V-Ag measured as in Fig. 2. (Lanes $a, d$ ) Mock-transfected cells; (lane $g$ ) mock-infected CV-1 cells; (lane $h$ ) SV40-infected CV-1 cells. This experiment was repeated once.

The object of this study was to determine which of these elements was also required to regulate gene expression in mammalian germ cells. To this end, we injected various SV40 DNA sequences (Fig. 1) into the germinal vesicle of mouse oocytes and measured expression of early $(\mathrm{T}-\mathrm{Ag}, \mathrm{t}-\mathrm{Ag})$ and late $(\mathrm{V}-\mathrm{Ag})$ gene products. Our results are summarized in Table 2 and compared with data from analogous experiments carried out with differentiated mammalian cells and Xenopus laevis oocytes. Five important conclusions concerning regulation of gene expression in mammalian cells can be drawn from our observations, and these conclusions bear on the relationship between mammalian and amphibian oocytes as systems for study of gene expression and DNA replication.

First, the promoter for SV40 early and late gene expression in mouse oocytes includes the same GGGCGG boxes required in mammalian differentiated cells. In vitro, GGGCGG boxes interact with cellular proteins Spl (Dynan and Tjian 1985) and LSF (Kim et al. 1987), which stimulate both early and late gene transcription. Spl has been shown to act on a variety of cellular and viral gene promoters (McKnight and Tiian 1986). Deletion of GGCGG boxes 4, 5, and 6 did not impair T-Ag expression in mouse oocytes although it did reduce $\mathrm{V}-\mathrm{Ag}$ synthesis slightly (mutant XS7, table 1), but further deletion of GGGCGG boxes reduced both $\mathrm{T}-\mathrm{Ag}$ and $\mathrm{V}-\mathrm{Ag}$ expression from 4- to 20-fold (mutants XS14, XS15, and XS16, Table 1). The effect on V-Ag synthesis did not result indirectly from loss of $\mathrm{T}-\mathrm{Ag}$ synthesis $(\mathrm{T}-\mathrm{Ag}$ is required for trans-activation of the late gene promoter), because additional $\mathrm{T}-\mathrm{Ag}$ provided by coinjection of p/YM was unable to stimulate $\mathrm{V}$ - $\mathrm{Ag}$ expression in the absence of GGGCGG boxes (Table 1). Thus, Sp1 and LSF appear to be present in mammalian germ cells, as well as differentiated cells.

Deletions that bring the GGGCGG boxes to within 115 or $50 \mathrm{bp}$ of the major late mRNA start sites increase late gene transcription 2- to 10-fold in differentiated cells (Hansen and Sharp 1983; Rio and Tiian 1984; Vigneron et al. 1984; Omilli et al. 1986). Therefore, V-Ag synthesis in mutants XS7, XS11, XS13, S113, and S232 may have been augmented by this phenomenon because these deletions (Fig. 1) decreased the distance between TATA and GGGCGG boxes and the late gene mRNA start sites. This may have been particularly evident in $\mathrm{S} 232$, which contains the largest deletion; yet V-Ag expression is reduced only twofold whereas $\mathrm{V}-\mathrm{Ag}$ expression in XS13 and S113 was reduced four- to sixfold. Interestingly, the deletion in XS6 brought the early gene TATA box and surrogate TATA-like box of the late genes closer together. This may explain the slight increase in V-Ag synthesis relative to mutants XS14, XS15, and XS16 (Table 1). Nandi et al. (1985) have shown that conversion of the late gene surrogate TATA box to a form that more closely resembles the early gene TATA box enhances late gene synthesis four- to eightfold. There was no correlation between deletion of major late RNA start sites and V-Ag synthesis.

Our second conclusion is that expression of SV40 early genes in mouse oocytes does not require a 72-bp repeat, in contrast to differentiated cells. Since the 72-bp repeat functions as an enhancer element in mouse cells as well as monkey and human cells (Capecchi et al. 1983), it was surprising that deletions removing one or both of the 72-bp repeats XS11 and XS13, respectively (Fig. 1), did not reduce T-Ag expression in mouse oocytes; in fact, T-Ag expression was somewhat increased (Table 1). This was further substantiated using plasmids in which E. coli chloramphenicol transacetylase (CAT) gene is coupled to the herpes simplex virus thymidine kinase promoter. The level of CAT expression was not affected by the presence or absence of polyoma virus enhancer elements (DePamphilis et al. 1987; unpubl. data). The 72-bp repeats are important primarily for initiation of mRNA synthesis at early-early (E-E)-mRNA start sites (Fig. 1) and are not required for initiation at late-early (L-E)-mRNA start sites used following the onset of viral DNA replication (Buchman et al. 1984). In this respect, expression of $\mathrm{T}-\mathrm{Ag}$ in mouse oocytes resembles $\mathrm{T}-\mathrm{Ag}$ expression late during infection of permissive cells when late genes are also expressed. We have previously shown that one oocyte produces as much SV40 gene products as 


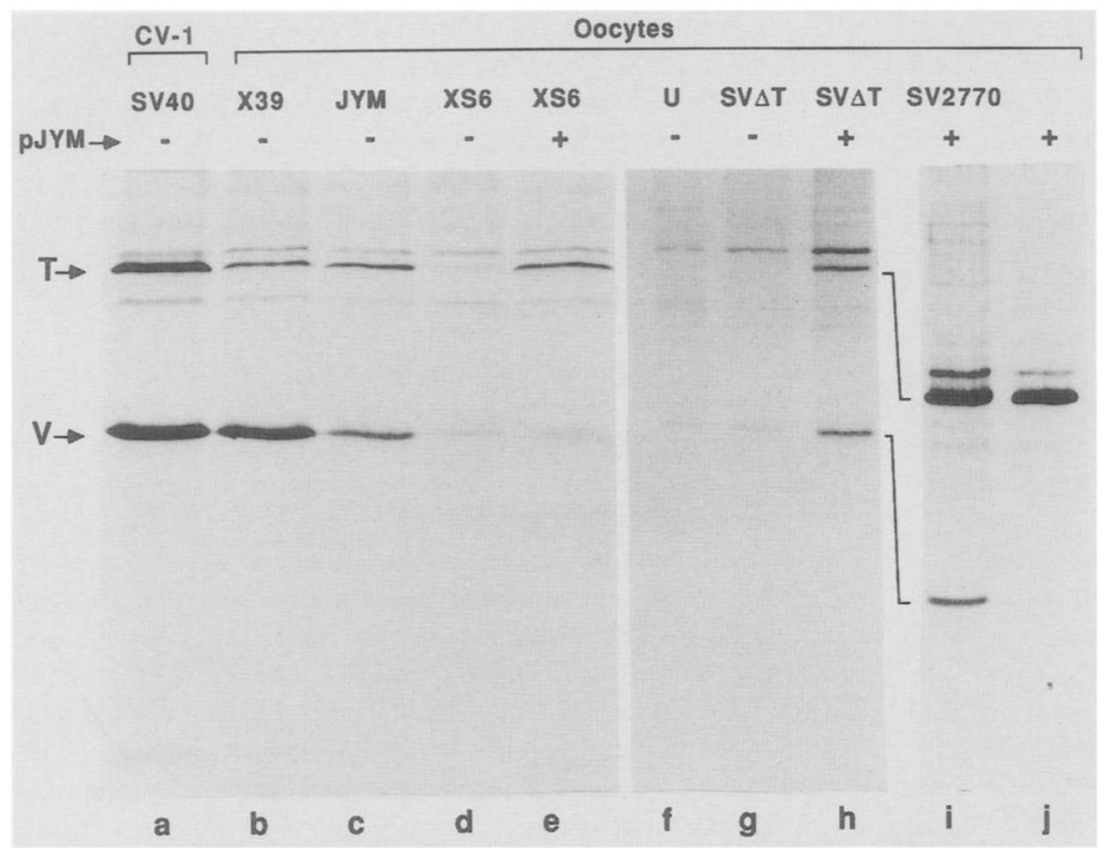

Figure 6. Requirement of $\mathrm{T}-\mathrm{Ag}$ for $\mathrm{V}-\mathrm{Ag}$ expression in mouse oocytes. SV40 DNA from mutants X39, XS6, XS7, XS14, XS15, SVDT, and SV2770 was prepared for injection as described in Fig. 2. Lanes: $(a)$ SV40-infected CV-1 cells; (b) X39; (c) JYM; (d) XS6; (e) $\mathrm{XS6}+$ pJYM; $(f)$ uninjected; $(g)$ SV $\Delta \mathrm{T},(h)$ SV $\Delta \mathrm{T}+$ pJYM; (i) SV2770+pJYM; (j) pJYM alone. PJYM was absent $(-)$ or coinjected $(+)$ in equimolar amounts to the test DNA indicated. about 1000 virus-infected permissive monkey cells (Chalifour et al. 1986). Thus, mouse oocytes may have such high concentrations of RNA polymerase II initiation factors that an enhancer function is no longer required to achieve the highest rate of promoter activity.

Third, DNA replication is not required to achieve a level of late gene expression equivalent to or greater than that of early gene expression. Late gene expression was, on average, three to four times greater than early gene expression in mouse oocytes (Table 1; Chalifour et al. 1986). However, neither polyoma nor SV40 DNA replicates when injected into the germinal vesicle of mouse oocytes, and oocytes themselves are not engaged in DNA replication because they are arrested in diplotene of the first meiotic prophase (Wirak et al. 1985; Chalifour et al. 1986). Furthermore, expression of SV40 early and late genes in mouse oocytes was unaffected by deletion of ori sequences that included $\mathrm{T}-\mathrm{Ag}$ binding site 2 (mutants $\Delta 6-1$ and X39, Table 1). Microinjection of SV40 DNA into differentiated cells in culture revealed that DNA replication was required for high expression of
$\mathrm{V}-\mathrm{Ag}$ in permissive monkey cells regardless of the amount of viral DNA injected (Graessman et al. 1977), but that high concentrations of SV40 DNA (2000-4000 copies per cell) injected into nonpermissive mouse $3 \mathrm{~T} 3$ cells resulted in V-Ag synthesis (Graessman et al. 1976). We routinely injected $17,000-85,000$ copies of DNA per oocyte, which was equivalent to 80-400 DNA molecules injected into differentiated cells in culture. Thus, it appears that mouse oocytes express a cellular factor that allows efficient expression of the late gene promoter in the absence of DNA replication. The concentration of this cellular factor must be reduced in mouse fibroblasts, and still lower in monkey fibroblasts.

Fourth, $\mathrm{T}-\mathrm{Ag}$ induces a permissive cell factor(s) in mouse oocytes that is required for SV40 late gene expression. Nucleotides 168-200 are involved in trans-activation of the SV40 late gene promoter by $\mathrm{T}-\mathrm{Ag}$ during infection of permissive monkey cell cultures (Hartzell et al. 1984a,b; Brady and Khoury 1985; Keller and Alwine 1985). T-Ag is also required for expression of late genes in mouse oocytes (Table 1), and sequences between nu-

Table 2. Requirements for optimal expression of SV4O genes in germ cells and in differentiated permissive mammalian cells

\begin{tabular}{|c|c|c|c|c|c|c|}
\hline \multirow{2}{*}{$\begin{array}{l}\text { Sequence } \\
\text { or function }\end{array}$} & \multicolumn{2}{|c|}{$\begin{array}{l}\text { Differentiated } \\
\text { cells }\end{array}$} & \multicolumn{2}{|c|}{$\begin{array}{l}\text { Mouse } \\
\text { oocyte }\end{array}$} & \multicolumn{2}{|c|}{$\begin{array}{l}\text { Xenopus } \\
\text { oocyte }\end{array}$} \\
\hline & Early & Late & Early & $\overline{\text { Late }}$ & Early & Late \\
\hline $\mathrm{T}$-Ag protein & - & + & - & + & - & - \\
\hline DNA replication & - & + & - & - & - & - \\
\hline ori & - & + & - & - & ND & $+1-$ \\
\hline TATA box & - & - & - & - & ND & - \\
\hline GGGCGG boxes & + & + & + & + & ND & - \\
\hline 72-bp repeat ('enhancer') & + & $+^{*}$ & - & $+^{*}$ & + & $+^{*}$ \\
\hline
\end{tabular}

The indicated sequence or function is either required $(+)$ or not required $(-)$ for optimal expression of the early or late SV40 promoter. (ND) The experiment has not been reported; $\left(+^{*}\right)$ part of the 72 -bp sequence is required, but it may not function as an enhancer; $(+/-)$ conflicting results. See text for details. 
cleotides 197 and 273 enhance late gene expression in mouse oocytes since deletion of this region reduced $\mathrm{V}-\mathrm{Ag}$ synthesis by $80 \%$ (Table 1 ). This sequence contains elements important for enhancer function (Herr and Clarke 1986; Wildeman et al 1986; Zenke et al. 1986; Schirm et al. 1987), and the enhancer border has been extended to include these more upstream sequences (Firak and Subramanian 1986). Although it is difficult to relate enhancer activity directly to late gene expression, in light of the inability of these sequences to enhance early gene expression, one or more enhancer elements may function in a novel way by interacting with either a T-Ag : cellular protein complex or a cellular protein whose synthesis is induced by T-Ag. trans-activation by $\mathrm{T}-\mathrm{Ag}$ does not appear to involve binding of $\mathrm{T}-\mathrm{Ag}$ directly to the enhancer sequence, because transactivation does not require either T-Ag DNA binding sites or a functional $\mathrm{T}-\mathrm{Ag}$ at the time when gene expression is activated (Robbins et al. 1986). Similarly, expression of $\mathrm{T}-\mathrm{Ag}$ in differentiated cells induces expression of cellular genes that do not contain $\mathrm{T}$-Ag binding sites (Scott et al. 1983; Singh et al. 1985), and T-Ag mutants that are deficient in binding DNA are still capable of immortalizing rodent cells (Cowie et al. 1986). Therefore, $\mathrm{T}-\mathrm{Ag}$ does not have to bind directly to a gene to affect its synthesis. Two-dimensional gel electrophoresis of ${ }^{35} \mathrm{~S}$ labeled proteins synthesized in oocytes did not reveal differences between oocytes injected with SV40 DNA and noninjected oocytes (data not shown), suggesting that $\mathrm{T}-\mathrm{Ag}$ did not alter protein synthesis in germ cells. However, since mouse oocytes express both $\mathrm{T}-\mathrm{Ag}$ and $\mathrm{V}-\mathrm{Ag}$ concurrently and at equivalent levels, the permissive cell protein required for late gene expression may already be present at high concentrations in oocytes where, together with $\mathrm{T}-\mathrm{Ag}$, it activates late gene expression. In contrast, $\mathrm{T}-\mathrm{Ag}$ must induce synthesis of low concentrations of this protein in differentiated cell lines, thus explaining the delay in $\mathrm{V}-\mathrm{Ag}$ synthesis and the requirement for gene amplification to achieve high levels of protein synthesis.

Gorman et al. (1985) demonstrated a dose-dependent, enhancer-independent expression of $\mathrm{T}-\mathrm{Ag}$ in undifferentiated embryonal carcinoma (EC) cells transfected with SV40 DNA. Differentiation of EC cells restored enhancer-dependent expression. The negative modulator postulated by Gorman et al. (1985) may be present in preimplantation mouse embryos, since neither SV40specific mRNA nor immunoprecipitable T-Ag and V-Ag is detected (Chalifour et al. 1986).

Finally, regulation of gene expression in mammalian oocytes is distinctly different from that in amphibian oocytes (Table 2). Xenopus laevis oocytes also express SV40 genes when SV40 DNA is injected into the germinal vesicle, and the late promoter is transcribed at least 10 -fold more efficiently than the early promoter (Michaeli and Prives 1985; Green et al. 1987). However, in contrast to mouse oocytes, late gene expression in Xenopus oocytes does not require either T-Ag (Michaeli and Prives 1985; Green et al. 1987) or GGGCGG boxes (Contreras et al. 1982; Green et al. 1987), and early gene expression is stimulated 10- to 100 -fold by the 72 -bp re- peats (Spinelli and Ciliberto 1985). SV40 late gene expression in Xenopus oocytes is similar to expression in mouse oocytes in that it does not require a TATA box and does respond to nucleotides 128-270, encompassing part of the 72-bp repeat region (Green et al. 1987). A requirement for ori has been observed in some experiments (Contreras et al. 1982) but not in others (Green et al). Unlike the SV40 enhancer, the mouse immunoglobulin, human $\alpha_{1}$-antitrypsin, Moloney murine sarcoma virus, and human c-myc enhancers have no apparent effect on gene expression in Xenopus oocytes (Spinelli and Ciliberto 1985; Graves et al. 1985; Nishikura 1986). These data show that Xenopus oocytes utilize different sequences than do mouse oocytes or mammalian differentiated cells to initiate mRNA synthesis from SV40 early and late genes (Table 2). It appears that the unusually high concentration of proteins synthesized and stored in Xenopus oocytes allows them simply to stimulate the basal level of gene activity observed in mouse oocytes. Thus, mechanisms that regulate gene expression in germ cells of one vertebrate are not necessarily observed in another.

\section{Materials and methods}

Plasmids X39, XS11, XS13, S113, S232, XS7, XS14, XS15, and XS16 were originally provided by P. Berg (Stanford). Plasmids pJYM and pML-1 were a gift from M. Botchan (University of California, Berkeley). Plasmid $\mathrm{p} \Delta 6-1$ was a gift from $Y$. Gluzman (Cold Spring Harbor Laboratory). COS-7 and CV-1 cells were obtained from the American Type Culture Collection.

\section{Construction of pSVAT, pSVALL, and pSV2770}

To generate pSV $\Delta \mathrm{T}$, SV40 wild-type DNA was cut with Nde I, which cuts at nucleotides 3808 and 4826 in the early gene coding sequences. The large fragment was isolated, ligated to itself, then recut with BamHI, which cuts at nucleotide 2533 in the late coding sequence, and cloned into the BamHI site of pML-1 (Maniatis et al. 1982). The absence of the Nde I small fragment 4826-3808 was confirmed by restriction enzyme analysis. To generate pSV $\Delta L L_{,}$, SV40 wild-type DNA was cut with Hhal which cuts at nucleotide 343 and 833 in the late coding sequences. The large fragment was then cloned as described above into the BamHI site of pML-1. The absence of the Hhal small fragment was confirmed by restriction enzyme analysis. To generate pSV2770, SV40 wild-type DNA was cut with BclI, which cuts at nucleotide 2770 in the carboxyl-terminus of the early genes, then cloned into the BamHI site of pML-1.

\section{Expression of SV40 genes in mouse oocytes}

Isolation, injection, and culturing of mouse oocytes and immunoprecipitation of virally encoded antigens have been described previously (Wirak et al. 1985; Chalifour et al. 1986). Preparation of covalently closed, superhelical SV40 and plasmid DNA (Form 1) was carried out as described previously (Wirak et al. 1985). Oocytes isolated from two to three animals were pooled and injected on the same day. Each lane on each gel contained lysate from the same number of oocytes. Acid-precipitable $\left[{ }^{35} \mathrm{~S}\right]$ methionine was assayed in each sample prior to im- 
munoprecipitation and did not vary significantly between samples.

\section{Preparation of DNA for injection}

To delete plasmid sequences from recombinant plasmids and to generate circular DNA in which the control sequences were in cis to early and late gene sequences, $25 \mu \mathrm{g}$ of plasmid DNA was cleaved with BamHI to remove the SV40 from vector sequences. The DNA mixture was religated in $12.5 \mathrm{ml}$ of ligation buffer (Maniatis et al. 1982) with $10 \mu$ l of T4 DNA ligase (New England Bio-Labs) for $12-16 \mathrm{hr}$ at $15^{\circ} \mathrm{C}$. The religated DNA was extracted with phenol/chloroform $(1: 1)$, then chloroform/ isoamyl alcohol $(24: 1)$, and dialyzed extensively against TE [10 mM Tris (pH 7.8), 1 mM EDTA]. DNA was concentrated with sec-butanol and passed through a 5-ml column of P-100 (BioRad) equilibrated with TEN20 (TE plus $20 \mathrm{mM} \mathrm{NaCl}$ ). The purified DNA was precipitated with ethanol, then resuspended to $0.1-0.5 \mathrm{mg} \mathrm{DNA} / \mathrm{ml}$ in injection buffer. Agarose gel electrophoresis revealed that $75 \%$ of the DNA were circular monomers.

\section{Acknowledgments}

We are indebted to Dr. Claude Lechene (Harvard Medical School) for providing the facilities to make micropipettes, to Shawn Fields-Berry for construction of $\mathrm{p} \Delta \mathrm{LL}$, to Margaret Gomes for excellent technical assistance, and to Rosario Perona for many helpful discussions. This work was supported by grants from the National Institues of Health, American Cancer Society, and the American Heart Association. L.E.C. was supported by a fellowship from the Leukemia Society of America, Inc, and D.O.W. by a fellowship from the National Cancer Institute.

\section{References}

Acheson, N.H. 1981. Lytic cycle of SV40 and polyoma virus. In DNA tumor viruses (ed. J.R. Tooze), pp. 125-205. Cold Spring Harbor Laboratory, Cold Spring Harbor, New York.

Barrera-Saldana, H., K. Takahashi, M. Vigneron, A. Wildeman, and P. Chambon. 1986. All six GC-motifs of the SV40 early upstream element contibute to promoter activity in vivo and in vitro. EMBO I. 4: 3839-3849.

Baty, D., H.A. Barrera-Saldana, R.D. Everett, M. Vigneron, and P. Chambon. 1984. Mutational dissection of the 21 bp repeat region of the SV40 early promoter reveals that it contains overlapping elements of the early-early and late-early promoters. Nucleic Acids Res. 12: 915-932.

Benoist, C. and P. Chambon. 1981. In vivo sequence requirements of the SV40 early promoter region. Nature 290: 304 309.

Brady, J. and G. Khoury. 1985. Trans activation of the simian virus 40 late transcription unit by T-antigen. Mol. Cell. Biol. 5: $1391-1399$.

Brady, J., M. Radonovich, M. Thoren, G. Das, and N.P. Salzman. 1984a. Simian virus 40 major late promoter: An upstream DNA sequence required for efficient in vitro transcription. Mol. Cell. Biol. 4: 133-14l.

Brady, J., J.B. Bolen, M. Radonovich, N.P. Salzman, and G. Khoury. 1984b. Stimulation of simian virus 40 late gene expression by simian virus 40 tumor antigen. Proc. Natl. Acad. Sci. 81: 2040-2044.

Buchman, A.R., L. Burnett, and P. Berg. 1981. The SV40 nucleotide sequence. In DNA tumor viruses (ed. J.R. Tooze), pp. 799-842. Cold Spring Harbor Laboratory, Cold Spring Harbor, New York.
Buchman, A.R., M. Fromm, and P. Berg. 1984. Complex regulaton of simian virus 40 early-region transcription from different overlapping promoters. Mol. Cell. Biol. 4: 1900-1914.

Capecchi, M.R., P.A. Luciw, J.M. Bishop, and H.E. Varmus. 1983. Location and function of retroviral and SV40 sequences that enhance biochemical transformation after microinjection of DNA. In Enhancers and eukaryotic gene expression (ed. Y. Gluzman and T. Shenk) pp. 101-102. Cold Spring Harbor Laboratory, Cold Spring Harbor, New York.

Chalifour, L.E., D.O. Wirak, P.M. Wassarman, and M.L. DePamphilis. 1986. Expression of simian virus 40 early and late genes in mouse oocytes and embryos. J. Virol. 59: 619627.

Chia, W. and P.W.J. Rigby. 1981. Fate of viral DNA in nonpermissive cells infected with simian virus 40 . Proc. Natl. Acad. Sci. 78: 6638-6642.

Contreras, R., D. Gheysen, J. Knowland, A. S.C. van de Voorde, and W. Fiers. 1982. Evidence for the direct involvement of DNA replication origin in synthesis of late SV40 RNA. Nature 300: 500-505.

Cowie, A., J. de Villiers, and R. Kamen. 1986. Immortalization of rat embryo fibroblasts by mutant polyomavirus large $\mathrm{T}$ antigens deficient in DNA binding. Mol. Cell. Biol. 6: 4344-4352.

DePamphilis, M.L. and M.K. Bradley. 1986. Replication of SV40 and polyoma virus chromomosomes. In The papovaviridae (ed N.P. Salzman), vol. 1, pp. 99-246. Plenum Press, New York.

DePamphilis, M.L., R.S. Decker, M. Yamaguchi, R. Possenti, D.O. Wirak, R. Perona, and J.A. Hassell. 1987. Transcriptional elements and their role in activation of simian virus 40 and polyoma virus origins of replicaton. In DNA replication and recombination (ed. T. Kelly and R. McMacken), pp. 367-379. Alan R. Liss, New York.

Dynan, W.S. and R. Tjian. 1985. Control of eukaryotic messenger RNA synthesis by sequence-specific DNA-binding proteins. Nature 316: $774-778$.

Ernoult-Lange, M. and E. May. 1983. Evidence of transcription from the late region of the integrated simian virus 40 genome in transformed cells: Location of the $5^{\prime}$ ends of late transcripts in cells abortively infected and in cells transformed by simian virus 40. J. Virol 46: 756-767.

Ernoult-Lange, M., P. May, P. Moreau, and E. May. 1984. Simian virus 40 late promoter region able to initiate simian virus 40 early gene transcription in the absence of the simian virus 40 origin sequences. J. Virol. 50: 163-173.

Ernoult-Lange, M., F. Omilli, D.R. O'Reilly, and E. May. 1987. Characterization of the simian virus 40 late promoter: Relative importance of sequences within the 72-base-pair repeats differs before and after viral DNA replication. I. Virol. 61: $167-176$.

Everett, R.D., D. Baty, and P. Chambon. 1983. The repeated GC-rich motifs upstream from the TATA box are important elements of the SV40 early promoter. Nucleic Acids Res. 11: $2447-2464$.

Firak, T.A. and K.N. Subramanian. 1986. Minimal transcriptional enhancer of simian virus 40 is a 74 -base-pair sequence that has interacting domains. Mol. Cell. Biol. 6: 3667-3676.

Fromm, M. and P. Berg. 1982. Deletion mapping of DNA regions required for SV40 early region promoter function in vivo. J. Mol. Appl. Genet. 1: 457-481.

. 1983a. Transcription in vivo from SV40 early promoter deletion mutants without repression by large $\mathrm{T}$ antigen. $J$. Mol. Appl. Genet. 2: 127-135.

1983b. Simian virus 40 early- and late-region promoter functions are enhanced by the 72 -base-pair repeat inserted at 
distant locations and inverted orientations. Mol. Cell. Biol. 3: $991-999$.

Gidoni, D., J.T. Kadonaga, H. Barrera-Saldana, K. Takahashi, P. Chambon, and R. Tjian. 1985. Bidirectional SV40 transcription mediated by tandem Spl binding interactions. Science 230: $511-517$.

Gluzman, Y. 1981. SV40-transformed simian cells support the replication of early SV40 mutants. Cell 23: 175-182.

Gorman, C.M., P.W.J. Rigby, and D.P. Lane. 1985. Negative regulation of viral enhancers in undifferentiated embryonic stem cells. Cell 42: 519-526.

Graessmann, A., M. Graessmann, and C. Mueller. 1976. Regulatory mechanism of simian virus 40 gene expression in permissive and in nonpermissive cells. J. Virol. 17: 854-858.

. 1977. Regulatory function of simian virus 40 DNA replication for late viral gene expression. Proc. Natl. Acad. Sci. 74: $4831-4834$.

Graves, B.J., R.N. Eisenman, and S.L. McKnight. 1985. Delineation of transcriptional control signals within the Moloney murine sarcoma virus long terminal repeat. Mol. Cell. Biol. 5: $1948-1958$.

Green, I., J. Brady, and G. Khoury. 1987. 72-bp element contains a critical control region for SV40 late expression in Xenopus laevis oocytes. Virology 159: 339-349.

Hansen, U. and P. Sharp. 1983. Seqeunces controlling in vitro transcription of SV40 promoters. EMBO I. 2: 2293-2303.

Hartzell, S.W., B. Byrne, and K.N. Subramanian. 1984a. The simian virus 40 minimal origin and the 72 -base-pair repeat are required simultaneously for efficient induction of late gene expression with large tumor antigen. Proc. Natl. Acad. Sci. 81: 6335-6339.

. 1984b. Mapping of the late promoter of simian virus 40 . Proc. Natl. Acad. Sci. 81: 23-27.

Herr, W. and J. Clarke. 1986. The SV40 enhancer is composed of multiple functional elements that can compensate for one another. Cell 45: 461-470.

Keller, J.M. and J.C. Alwine. 1984. Activation of the SV40 late promoter: Direct effects of $T$ antigen in the absence of viral DNA replication. Cell 36: 381-389.

1985. Analysis of an activatable promoter: Sequences in the simian virus 40 late promoter required for $\mathrm{T}$-antigen mediated trans activation. Mol. Cell. Biol. 5: 1859-1869.

Kim, C.H., C. Heath, D. Bertuch, and U. Hansen. 1987. Specific stimulation of simian virus 40 late transcription in vitro by a cellular factor binding the simian virus 4021 -base-pair repeat promoter element. Proc. Natl. Acad. Sci. 84: 60256029.

Lusky, M. and M. Botchan. 1981. Inhibition of SV40 replication in simian cells by specific pBR322 DNA sequences. Nature 293: $79-81$.

Luthman, H. and G. Magnusson. 1983. High efficiency polyoma DNA transfection of chloroquine treated cells. Nucleic. Acids Res. 11: 1295-1308.

Maniatis, T., E.F. Fritsch, and J. Sambrook. 1982. Molecular cloning: A laboratory manual. Cold Spring Harbor Laboratory, Cold Spring Harbor, New York.

McKnight, S. and R. Tjian. 1986. Transcriptional selectivity of viral genes in mammalian cells. Cell 46: 795-805.

Michaeli, T.and C. Prives. 1985. Regulation of simian virus 40 gene expression in Xenopus laevis oocytes. Mol. Cell. Biol. 5: 2019-2028.

Miller, T.J. and J.E. Mertz. 1982. Template structural requirements for transcription in vivo by RNA polymerase II. Mol. Cell. Biol. 2: 1595-1607.

Nandi, A., G. Das, and N.P. Salzman. 1985. Characterization of a surrogate TATA box promoter that regulates in vitro tran- scription of the simian virus 40 major late gene. Mol. Cell. Biol. 5: 591-594.

Nishikura, K. 1986. Sequences involved in accurate and efficient transcription of human c-myc genes microinjected into frog oocytes. Mol. Cell. Biol. 6: 4093- 4098.

Omilli, F., M. Ernoult-Lange, J. Borde, and E. May. 1986. Sequences involved in initiation of simian virus 40 late transcription in the absence of $\mathrm{T}$ antigen. Mol. Cell. Biol. 6: $1875-1885$.

Parker, B.A. and G.R. Stark. 1979. Regulation of simain virus 40 transcription: Sensitive analysis of the RNA species present early in infections by virus or viral DNA. J. Virol. 31: 360369.

Rio, D.C. and R. Tjian. 1984. Multiple control elements involved in the initiation of SV40 late transcription. I. Mol. Appl. Genet. 2: 423-435.

Robbins, P.D., D.C. Rio, and M.R. Botchan. 1986. Trans activation of the simian virus 40 enhancer. Mol. Cell. Biol. 6: $1283-1295$.

Schirm, S., J. Jiricny, and W. Schaffner. 1987. The SV40 enhancer can be dissected into multiple segments, each with a different cell type specificity. Genes Dev. 1: 65-74.

Scott, M.R.D., K.H. Westphal, and P.W.J. Rigby. 1983. Activation of mouse genes in transformed cells. Cell 34: 557-567.

Shaw, P.E., D. Bohmann, and A. Sergeant. 1985. The SV40 enhancer influences viral late transcription in vitro and in vivo but not on replicating templates. EMBO I. 4: 3247-3252.

Singh, K., M. Carey, S. Saragosti, and M. Botchan. 1985. Expression of enhanced levels of small RNA polymerase III transcripts encoded by the B2 repeats in simian virus 40-transformed mouse cells. Nature 314: 553-556.

Slack, J.M.W. 1983. From egg to embryo. Cambridge University Press, Cambridge.

Spinelli, G. and G. Ciliberto. 1985. Functional activity and chromatin confirguration of SV40 enhancer injected Xenopus laevis oocytes. Nucleic Acids Res. 13: 8065-8081.

Takahashi, K., M. Vigneron, H. Matthes, A.G. Wildeman, M. Zenke, and P. Chambon. 1986. Requirement of stereospecific alignments for initiation from the simian virus 40 early promoter. Nature 319: 121-126.

Thomas, P.G. and M.B. Mathews. 1980. DNA replication and the early to late transition in adenovirus infection. Cell 22: $523-533$.

Vigneron, M., H.A. Barrera-Saldana, D. Baty, R.E. Everett, and P. Chambon. 1984. Effect of the 21-bp repeat upstream element on in vitro transcription from the early and late SV40 promoters. EMBO I. 3: 2373-2382.

Wasylyk, B., C. Wasylyk, P. Augereau, and P. Chambon. 1983. The SV40 72 bp repeat preferentially potentiates transcription starting from proximal natural or substitute promoter elements. Cell 32: 503-514.

Wildeman, A.G., M. Zenke, C. Schatz, M. Wintzerith, T. Grundstrom, H. Matthes, K. Takahashi, and P. Chambon. 1986. Specific protein binding to the simian virus 40 enhancer in vitro. Mol. Cell. Biol. 6: 2098-2105.

Wirak, D.O., L.E. Chalifour, P.M. Wassarman, W.J. Muller, J.A. Hassell, and M.L. DePamphilis. 1985. Sequence dependent DNA replication in preimplantation mouse embryos. Mol. Cell. Biol. 5: 2924-2935.

Yaniv, M. 1984. Regulation of eukaryotic gene expression by trans activating proteins and cis acting DNA elements. Biol. Cell. 50: 203-216.

Zenke, M., T. Grundstrom, T. Matthes, M. Wintzerith, C. Schatz, A.G. Wildeman, and P. Chambon. 1986. Multiple sequence motifs are involved in SV40 enhancer function. $E M B O$ J. 5: 387-397. 


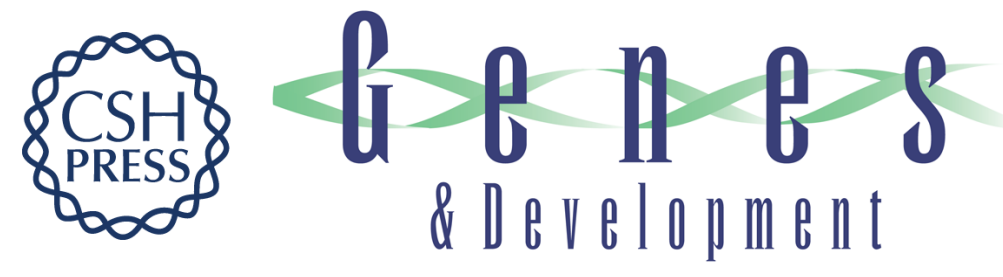

\section{cis- and trans-acting sequences required for expression of simian virus $\mathbf{4 0}$ genes in mouse oocytes.}

L E Chalifour, D O Wirak, U Hansen, et al.

Genes Dev. 1987, 1:

Access the most recent version at doi:10.1101/gad.1.10.1096

References This article cites 58 articles, 30 of which can be accessed free at: http://genesdev.cshlp.org/content/1/10/1096.full.html\#ref-list-1

License

Email Alerting Receive free email alerts when new articles cite this article - sign up in the box at the top Service right corner of the article or click here.

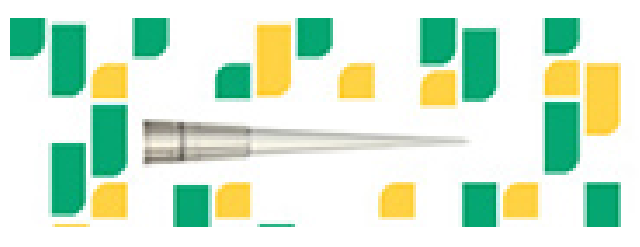

Focused on your science. 